\title{
Pelaksanaan Pelayanan Pemerintah Desa Terhadap Masyarakat Di Desa Rantau Panjang Kecamatan Sebawi Kabupaten Sambas
}

\author{
Hasiah $^{1}$, Tamrin Muchsin ${ }^{2}$, Somiadi $^{3}$, Tehedi $^{4}$, Nur Syamsiah ${ }^{5}$ \\ ${ }^{1}$ Institut Agama Islam Sultan Muhammad Syafiuddin Sambas, Jl. Raya Sejangkung No. 126, Sambas, 79463 \\ E-mail: hasiahrasyida@gmail.com \\ ${ }^{2}$ Institut Agama Islam Sultan Muhammad Syafiuddin Sambas, Jl. Raya Sejangkung No. 126, Sambas, 79463 \\ E-mail: - \\ ${ }^{3}$ Institut Agama Islam Sultan Muhammad Syafiuddin Sambas, Jl. Raya Sejangkung No. 126, Sambas, 79463 \\ E-mail: - \\ ${ }^{4}$ Institut Agama Islam Sultan Muhammad Syafiuddin Sambas, Jl. Raya Sejangkung No. 126, Sambas, 79463 \\ E-mail: - \\ ${ }^{5}$ Institut Agama Islam Sultan Muhammad Syafiuddin Sambas, Jl. Raya Sejangkung No. 126, Sambas, 79463 \\ E-mail: -
}

\begin{abstract}
This study aims to analyze the duties and authorities of the village government which is the leading government organization in the delivery of public services. Village government public services must be based on the minimum service standards as stated in the Regulation of the Minister of Home Affairs of the Republic of Indonesia Number 2 of 2017 concerning Village Minimum Service Standards that the Village Government must bring services closer to the community, facilitate services to the community, open service to the community and the effectiveness of services to the community. Public. This study uses a qualitative field research method with an empirical juridical approach. The results of the study concluded that there are still deficiencies in the implementation of the duties and authority of the village government in serving the community in Rantau Panjang. This is indicated by the fact that there are still people who do not have population data, there are concurrent positions in the Kasi and Kaur departments, and still not implemented regarding village determination regarding the village minimum service standard.
\end{abstract}

Keywords—: Service; Community; Village Government; Rantau Panjang.

\section{PENDAHULUAN}

Manusia pada dasarnya adalah mahluk sosial yang tidak dapat hidup sendiri. Manusia memiliki naluri untuk hidup dengan lainnya. Karena itulah, sejak dilahirkan manusia sudah mempunyai dua kecenderungan pokok, yaitu keinginan untuk menjadi satu dengan manusia lain disekelilingnya (masyarakat), dan keinginan untuk menjadi satu dengan suasana alam sekelilingnya. ${ }^{1}$ Kecenderungan manusia untuk hidup bersosial dan bermasyarakat sudah ada sejak lahir, itu merupakan asal mula terbentuknya masyarakat yang mempunyai hukum yang memiliki batas wilayah yang berwenang untuk mengatur dan mengurus urusan pemerintahannya sendiri dan pemerintahan jauh sebelum negara Indonesia terbentuk.

Sebelum masa reformasi telah dikenal kelompok masyarakat yang bermukim di suatu wilayah atau daerah tertentu dengan ikatan keturunan atau kekerabatan. Diera tersebut Desa merupakan kesatuan masyarakat terkecil, seperti sebuah rumah tangga besar yang di pimpin oleh anggota keluarga yang dituakan atau dihormati berdasarkan garis keturunan. ${ }^{2}$

Tahun 1999 bangsa Indonesia memasuki babak baru dalam penyelenggaraan otonomi daerah yang ditandai dengan UndangUndang Nomor 22 Tahun 1999 tentang Pemerintahan Daerah, yang kemudian dalam perkembangan selanjutnya diganti dengan Undang-Undang Nomor 32 Tahun 2004 sebagaimana telah diubah dengan Undang-Undang Nomor 12 Tahun 2008 tentang Perubahan Kedua atas Undang-Undang Nomor 32 Tahun 2004 tentang Pemerintahan Daerah yang sekarang diganti kembali dengan Undang-Undang Nomor 23 tahun 2014 tentang Pemerintah Daerah.

Ketentuan dalam Undang-Undang Nomor 23 Tahun 2014 tentang Pemerintahan Daerah, dan dipertegas kembali dalam Undang-undang Nomor 6 Tahun 2014 tentang Desa Pasal 1 (1), disebutkan bahwa Desa atau yang disebut dengan nama lain adalah kesatuan masyarakat hukum yang memiliki batas-batas wilayah yang berwewenang mengatur dan mengurus kepentingan masyarakat setempat, berdasarkan asal-usul dan hak tradisional yang diakui dalam sistem pemerintahan Negara Republik Indonesia. $^{3}$

\footnotetext{
${ }^{1}$ Ellya Rosana, “Dinamisasi Kebudayaan Dalam Realitas Sosial,” Jurnal Al-Adyan, Vol. 12, No. 1 Tahun 2017, hlm. 16

${ }^{2}$ Wahjudi Sumpeno, Perencanaan Desa Terpadu Edisi Kedua, Read (Reinforcament Action and Development, 2011), hlm. 1

${ }^{3}$ Pasal 1 ayat 1 Undang-Undang Nomor 6 tahun 2014 Tentang Desa
} 
Pemerintahan desa adalah penyelenggaraan urusan pemerintahan oleh Pemerintah Desa atau yang disebut dengan nama lain adalah Kepala Desa dan Parangkat Desa sebagai unsur penyelenggara pemerintahan desa. ${ }^{4}$ Kedudukan Desa sangat penting sebagai alat untuk mencapai tujuan didalam lembaga yang memperkuat struktur pemerintahan Negara Indonesia.

Desa merupakan institusi pemerintah terdepan yang dapat menjangkau kelompok sasaran yang akan disejahterakan, Desa sebagai lembaga pemerintahan, desa merupakan lembaga yang dapat memperkuat lembaga pemerintahan nasional, Desa merupakan pemerintah yang dapat menjangkau kelompok sasaran terdekat yang hendak disejahterakan sedangkan lembaga pemerintahan ini dapat berarti bahwa Pemerintah Desa merupakan organisasi pemerintah terdepan di dalam penyelenggaraan pelayanan publik.

Undang-Undang Nomor 25 Tahun 2009 Tentang Pelayanan Publik juga menyatakan kegiatan atau rangkaian kegiatan dalam rangka pemenuhan kebutuhan pelayanan bagi setiap warga negara atas barang dan jasa dan pelayanan administratif yang disediakan oleh penyelenggara publik sesuai aturan dan Undang-Undang yang berlaku. ${ }^{5}$

Pelayanan publik pemerintah desa harus berdasarkan standar minimal pelayanan bagaimana yang tercantum dalam Peraturan Menteri Dalam Negeri Repulik Indonesia Nomor 2 tahun 2017 tentang Standar Pelayanan Minimal Desa bahwa Pemerintah Desa harus mendekatkan pelayanan kepada masyarakat, mempermudah pelayanan kepada masyarakat, keterbukaan pelayanan kepada masyarakat dan efektifitas pelayanan kepada masyarakat.

Pelaksanaan standar minimal pelayanan Desa, Kepala Desa menetapkan keputusan Kepala Desa melalui surat Keputusan Kepala Desa. ${ }^{6}$ Dewasa ini kenyataannya penyelenggaraan pelayanan publik masih diperhadapkan pada kondisi yang belum maksimal dengan kebutuhan dan perubahan di berbagai bidang kehidupan bermasyarakat, berbangsa dan bernegara.

Ketidak siapan untuk menanggapi terjadinya transformasi nilai yang berdimensi luas serta dampak berbagai masalah pembangunan yang kompleks. Sementara itu tatanan baru masyarakat diperhadapkan pada harapan dan tantangan global yang dipicu oleh kemajuan di bidang ilmu pengetahuan, informasi dan komunikasi.

Kondisi macam ini perlu disikapi secara bijak melalui langkah-langkah kegiatan yang terus menerus dan berkesinambungan dalam berbagai aspek. Untuk itu, diperlukan konsepsi tentang pelayanan publik yang berisi nilai, persepsi, dan acuan perilaku yang mampu mewujudkan hak asasi manusia sebagaimana yang diamanatkan oleh UUD 1945 dapat diterapkan sehingga masyarakat memperoleh pelayanan sesuai dengan harapan dan cita-cita tujuan nasional. ${ }^{7}$

Kehadiran Peraturan Menteri Dalam Negeri Nomor 2 Tahun 2017 tentang Standar Pelayanan Minimal Desa diharapkan akan dapat Mendorong percepatan pelayanan kepada masyarakat, memberikan pelayanan kepada masyarakat sesuai kewenangannya, serta sebagai kontrol masyarakat terhadap kinerja Pemerintah Desa. ${ }^{8}$

Berdasarkan survei awal yang dilakukan didapati warga merasa kurang mendapatkan Pelayanan Publik, hal ini terbukti bahwa pelayanan yang dilaksanakan dikantor desa cukup rumit, karena informasi yang diberikan tidak komplit, saat melakukan administrasi didesa dengan meminta surat pernyataan pergantian nama KTP yang tidak sesuai begitu lama prosesnya. ${ }^{9}$ Hal senada disampaikan oleh Sekdes Rantau Panjang, bahwa Pemerintah Desa belum maksimal dalam melayani masyarakat terutama dalam hal pelayanan administrasi surat-menyurat yang lambat sehingga perlu adanya peningkatan pelayanan. Peningkatan pelayanan masyarakat tentunya mendisiplinkan tugas dan wewenang Pemerintah Desa.

Berangkat dari pernyataan diatas, maka tulisan ini bertujuan untuk menganalisis pelaksanaan pelayanan pemerintah desa terhadap masyarakat di Desa Rantau Panjang Kecamatan Sebawi Kabupaten Sambas. Adapun fokus penelitian antara lain: pertama, bagaimana pelaksanaan tugas dan wewenang pemerintah desa dalam melayani masyarakat di Desa Rantau Panjang Kecamatan Sebawi, dan kedua, apakah sudah sesuai menurut Peraturan Menteri Dalam Negeri Nomor. 2 Tahun 2017 tentang Standar Minimal Pelayanan Desa.

Penelitian ini menggunakan metode penelitian kualitatif lapangan dengan pendekatan Pendekatan yuridis normatif dan pendekatan yuridis empiris. ${ }^{10}$ Pendekatan penelitian yang digunakan oleh peneliti adalah pendekatan Yuridis Empiris yaitu penelitian dengan penelitian langsung kelapangan dengan metode wawancara, observasi, dan dokumentasi kepada objek masyarakat dan pemerintah desa disesuaikan dengan peraturan perundang-undangan yang nanti akan menjadi dasar untuk menjawab fokus permasalahan yang sesuai dengan judul artikel ini.

Sumber data adalah sumber pertama dimana sebuah data dihasilkan. Menurut Saifuddin Azwar data primer ialah data yang diperoleh peneliti secara langsung melalui wawancara mendalam dengan narasumber. ${ }^{11}$ Sumber data primer dalam penelitian ini diambil dari pemerintah di Desa Rantau Panjang yang bekerja di desa dalam memberikan pelayanan masyarakat desa. Menurut Sutrisno, data sekunder adalah data yang mendukung data primer serta data yang diperoleh dari luar objek penelitian sumber atau suber yang membantu memberi keterangan dan data pelengkap yang diperlukan data primer. ${ }^{12}$ Sumber data sekunder dapat

\footnotetext{
${ }^{4}$ Pasal 1 ayat 2 dan ayat 3 Undang-Undang Nomor 6 tahun 2014 Tentang Desa.

${ }^{5}$ Pasal 1 ayat 1 Undang-Undang Nomor 25 Tahun 2009 Tentang Pelayanan Publik

${ }^{6}$ Pasal 4 Peraturan Menteri Dalam Negeri Nomor 2 Tahun 2017 tentang Standar Minimal Pelayanan Desa

${ }^{7}$ Undang-Undang Nomor 25 Tahun 2009 Tentang Pelayanan Publik

${ }^{8}$ Pasal 3 Peraturan Menteri Dalam Negeri Nomor 2 Tahun 2017 Tentang Standar Pelayanan Minimal Desa

${ }^{9}$ Hasil Observasi Awal pada masyarakat Desa Rantau Panjang

${ }^{10}$ Soerjono Soekanto \& Sri Mamudji, Penelitian Hukum Normatif (Suatu Tinjauan Singkat), Jakarta, Rajawali Pers, 2001 , hlm 13

${ }^{11}$ Sifuddin Azwar, Metodologi Penelitian, Pustaka Pelajar, Yogyakarta, 1998, hlm. 91

${ }^{12}$ Sutrisno Hadi, Metedologi Research, Adi Offsed, Yogyakarta, 1993, hlm. 11
} 
berupa informasi dari Masyarakat setempat dan naskah (undang-undang atau peraturan), Sumber data sekunder tersebut terdiri dari :

1. Informasi dari masyarakat berupa wawancara lansung dilapangan dengan masyarakat Desa Rantau Panjang.

2. Peraturan perundang-undangan yang berlaku yaitu dari Undang-Undang Dasar 1945, Peraturan Menteri Dalam Negeri No. 2 Tahun 2017 Tentang Standar Minimal Pelayanan Desa, undang-undang No. 06 tahun 2014 Tentang Desa, dan Undangundang No. 25 tahun 2009 Tentang Pelayanan Publik.

\section{TINJAUAN TEORITIS}

Penelitian mengenai Pelaksanaan Tugas dan Wewenang Pemerintahan Desa telah banyak dilakukan, baik berupa skripsi, Jurnal dan karya ilmiah seperti:

Pertama Khlil Muslim "Pelaksanaan Tugas dan Fungsi Pemerintahan Kecamatan di Kota Makasar Dalam Pemberian Pelayanan Kepada Masyarakat". ${ }^{13}$ Penelitian ini bertujuan untuk mengetahui efektivitas pelaksanaan tugas dan fungsi pemerintahan Kecamatan Tamalanrea, Kecamatan Biringkanaya, dan Kecamatan Manggala di Kota Makasar dalam pemberian pelayanan kepada masyarakat dan untuk mengetahuai faktor-faktor yang berperan dalam pemberian pelayanan kepada masyarakat di Kecamatan Tamalanrea, Kecamatan Biringkanaya, dan Kecamatan Manggala. Peneliti ini dilakuakn di Kantor Camat Tamalanrea, Kantor Camat Biringkanaya, dan Kantor Camat Manggala dengan memberikan kuisioner kepada pihakpihak terkait untuk memperoleh data yang diperlukan. Hasil penelitian menunjukan bahwa pelaksanaan tugas dan fungsi pemerintahan kecamatan di kota Makassar belum efektif. Hal ini didasarkan pada pemberian pelayanan yang belum optimal oleh pegawai kecamatan serta minimnya pemahaman masyarakat terhadap pelayanan yang dimintakan. Pelayanan yang diberikan menurut peneliti belum sesuai dengan standar pelayanan serta belum memenuhi asas penyelenggaraan pelayanan publik seperti yang tertera dalam pasal 4 Undang-Undang No. 25 Tahun 2009 tentang Pelayanan Publik yaitu kepentinagan umum, kepastian hukum, kesamaan hak, keseimbangan hak dan kewajiban, keprofesionalan, partisifatif, persamaan perlakuan atau tidak diskriminatif, keterbukaan, akuntabilitas, fasilitas dan perlakuan khusus bagi kelompok rentan, ketepatan waktu, dan kecepatan, kemudahan, dan keterjangkauan.

Kedua, Peranan Kepala Desa Dalam Pelayanan Publik ( Studi Di Desa Pontak Kabupaten Minahasa Selatan) oleh Jamin Potabuga. ${ }^{14}$ Pelayanan publik bersifat melayani kepentingan umum tanpa kecuali yang melalui peranan pemerintahan bukan swasta. Melalui pemerintah tersedia barang milik publik yang kemudian digunakan untuk melayani kepentingan bersama. Kepala Desa Pontak dinilai berhasil dalam pelayanan publik di Sulawesi Utara sementara sebagian besar desa-desa dinilai kurang di bawah standar dalam pelayanan publik. Peranan kepala Desa Pontak dapat menjadi contoh, pernyataan konsep apa yang digunakannya sehingga berhasil. Menurut kepala Desa Pontak (Hukum Tua Pontak) Kepala desa di Minahasa disebut "hukum tua". Keberhasilan pemerintahan demokrasi ditentukan oleh keinginan mewujudkan kepentingan bersama menjadi niat dan tekat sebelum terpilih sebagai pemerintah. Setelah terpilih bulatkan niat dan tekat kita dan bertindak sebagai pemerintah pilihan terbaik rakyat. Hasil penelitian ini menunjukan bahwa keberhasilan pemerintah terpilih dalam pelayanan publik ditentukan oleh ada tidaknya niat dan tekad mewujudkan kepentingan bersama sebelum terpilih menjadi pemerintah.

Ketiga, Ricca Fauzia, "Peranan Pemerintah Desa untuk Mendorong Partisipasi Masyarakat dalam Pembangunan Desa di Desa Ngimbangan Kecamatan Mojosari Kabupaten Mojokerto". ${ }^{15}$ Dalam Penelitian ini dengan peneliti bertujuan untuk mengetahui: a) Bagaimana Program Pembangunan Desa di Desa Ngimbangan Kecamatan Mojosari Kabupaten Mojokerto; b) Bagaimana Partisipasi masyarakat dalam pembangunan Desa di Desa Ngimbangan Kecamatan Mojosari Kabupaten Mojokerto; c) Bagaimana peranan pemerintah desa untuk mendorong partisipasi masyarakat dalam pembangunan desa di Desa Ngimbangan Kecamtan Mojosari Kabupaten Mojokerto; d) Apakah Faktor-Faktor penghambat upaya mendorong partisipasi masyarakat dalam pembangunan desa di Desa Ngmbangan Kecamatan Mojosari Kabupaten Mojokerto; e) Bagaimana cara mengatasi faktor-faktor penghambat mendorong partisipasi masyarakat dalam pembangunan desa di Desa Ngimbangan Kecamatan Mojosari Kabupaten Mojokerto. Penelitian ini menggunakan pendekatan Kualitatif dengan jenis penelitian deskriftif ini, peneliti berusaha untuk menggambarkan bagaimana peranan pemerintah desa untuk mendorong partisipasi masyarakat dalam pembangunan desa.

Adapun hasil penelitian ini dapat dijabarkan sebagai berikut:

Pertama, program pembanguan Desa Ngimbangan Kecamatan Mojosari Kabupaten Mojokerto terbagi menjadi beberapa bidang, pemerintah desa mengelompokkannya dalam bidang pertanian, bidang sosial, bidang pendidikan, bidang kemasyarakatan, dan bidang umum.

Kedua, partisipasi masyarakat dalam pembangunan desa di desa Ngimbangan Kecamatan Mojosari Kabupaten Mojokerto dalam dalam keinginan untuk terlibat dalam pembanguan desa sangat tinggi terlihat dari kepartisipasiannya.

Ketiga, Peranan pemerintah desa untuk mendorong partisipasi masyarakat dalam pembangunan Desa di Desa Ngimbangan Kecamatan Mojosari Kabupaten Mojokerto dipengaruhi oleh cara yang dimiliki oleh pemerintah desa untuk mendorong partisipasi dan keikutsertaan pemerintah dalam pembangunan.

\footnotetext{
${ }^{13}$ Khalil Muslim, Pelaksanaan Tugas Dan Fungsi Pemerintah Kecamtan Di Kota Makasar Dalam Pemberian Pelayanan Kepada Masyarakat, Skripsi, 2013.

${ }^{14}$ Jamin Potabuga, "Peranan Kepala Desa Dalam Pelayanan Publik," dalam e-journal "Acta Diurna" Volume IV. No.2. Tahun 2015.

${ }^{15}$ Ricca Fauzia, Peranan Pemerintah Desa untuk mendorong Partisipasi Masyarakat dalam Pembangunan Desa di Desa Ngimbangan Kecamatan Mojosari Kabupaten Mojokerto. Skripsi: 2017.
} 
Website : http://yustisia.unmermadiun.ac.id/index.php/yustisia

Keempat, faktor-faktor penghambat upaya mendorong partisipasi masyarakat dalam pembangunan desa di Desa Ngimbangan Kecamatan Mojosari Kabupaten Mojokerto biasanya terjadi karena kekurangan pemahaman terhadap programkegiatan. Kelima, cara mengatasi faktor-faktor penghambat mendorong partisipasi masyarakat dalam pembangunan desa di Desa Ngimbangan Kecamtan Mojosari Kabupaten Mojokerto biasanya yaitu dengan cara memberikan pengarahan atau penyuluhan kepada masyarakat.

Beberapa hasil penelitian yang dipaparkan di atas terdapat perbedaan dalam penelitian yaitu aspek Pelaksanaan Tugas dan Fungsi dalam pelayanan Pemerintah Kecamatan, lokasi tempat penelitian dan Peran Pemerintah Desa, sedangkan peneliti meneliti tentang Pelaksanaan Tugas dan Wewenang Pemerintah Desa Dalam Melayani Masyarakat Di Desa Rantau Panjang Kecamatan Sebawi (Perspektif Peraturan Menteri Dalam Negeri Nomor 2 Tahun 2017 Tentang Standar Pelayanan Minimal Desa).

\section{HASIL PENELITIAN DAN PEMBAHASAN}

\section{A. Deskripsi Singkat Desa Rantau Panjang}

Desa Rantau Panjang merupakan salah desa yang ada di Kecamatan Sebawi Kabupaten Sambas. Secara historis Desa Rantau Panjang awalnya tergabung dari 4 dusun yaitu Dusun Rantau Timur, Rantau Barat, Dusun Hulu dan Hilir. Namun, setelah terbentuknya Kecamatan Sebawi tahun 2002, Dusun Hulu dan Dusun Hilir berubah menjadi Desa Semangau masuk ke dalam wilayah Kecamatan Sambas, sedangkan untuk Dusun Rantau Timur dan Rantau Barat Panjang berubah menjadi Desa Rantau Panjang yang masuk kedalam wilayah Kecamatan Sebawi. ${ }^{16}$

Desa Rantau Panjang atau disebut Semanjang merupakan Desa yang terdapat di Kecamatan Sebawi Kabupaten sambas, Kalimantan Barat yang memiliki luas $20 \mathrm{Km} 2$ (12,38\% dari wilayah Kecamatan Sebawi) dengan kepadatan penduduk berdasarkan sensus 2019 sebanyak 2.533 jiwa, yang terbagi atas 2 dusun yaitu Rantau Timur dan Rantau Barat dan 12 RT juga 11 RW. Posisi Kantor Desa di Dusun Rantau Timur Rt. 11 Rw. 06, Sedangkan Perangkat Desa yang berkerja sebanyak 11 orang yang terdiri dari 1 Kepala Desa, 1 Sekretaris Desa, 2 Kasi, 2 Kaur, 3 staf dan 2 Kepala Dusun yang masing masing menempati jabatannya. ${ }^{17}$

\section{B. Pelaksanaan Tugas dan Wewenang Pemerintah Desa Rantau Panjang dalam Melayani Masyarakat}

Desa Rantau Panjang merupakan desa yang masuk wilayah Kecamatan Sebawi yang terdiri dari 2.533 jiwa jumlah penduduk terdiri dari laki-laki 1.265 jiwa dan Perempuan 1.268 jiwa. Desa Rantau Panjang di pimpin oleh Kepala Desa yang bernama Heri Antoni pada periode 2019 - 2025. Kepala Desa sebagai pimpinan dalam kegiatan masyarakat di desa berkewajiban dan bertanggungjawab sepenuhnya dalam melayani keinginan dan keperluan masyarakat.

Kepala desa sebagai termasuk dalam Pemerintah desa yang memiliki wewenang yaitu:

1. Memimpin penyelenggaran Pemerintahan Desa;

2. Menetapkan Peraturan Desa;

3. Mengangkat dan memberhetikan Perangkat Desa;

4. Membina Masyarakat;

5. Menetapkan anggaran dan belanja desa;

6. Mengembangkan sumber pendapatan desa; dan

7. Melaksanakan wewenang lain sesuai dengan peraturan perundang-undangan. ${ }^{18}$

Sedangkan, tugas kepala desa adalah sebagai berikut :

1. Pembinaan Kepada Masyarakat;

2. Melaksanakan pembangunan desa;

3. Memberikan pemberdayaan kepada masyarakat desa; dan

4. Melaksanakan pemerintahan desa. ${ }^{19}$

Kepala Desa Rantau Panjang dalam menjalankan roda pemerintah dibantu oleh Sekretaris Desa, Perangkat Desa, dan Rt serta Rw di desa dengan jumlah Perangkat Pemerintah Desa 10 orang terdiri dari :

1. Sekretaris Desa

Sekretaris Desa Rantau Panjang Dalam menjalankan roda Pemerintah sebagai pembantu Kepala Desa 1 (satu) orang dijabat oleh Dadi mempunyai tugas yaitu membantu kepala desa dalam bidang administrasi seperti:

a) Administrasi surat menyurat, tata naskah dan arsip;

b) Penataan Administrasi Perangkat Desa, penyedian prsarana Perangakat dan kantor Desa, penyiapan rapat, Pengadministasian aset, inventaris, perjalan dinas, dan pelayanan umum.

\footnotetext{
${ }^{16}$ RPJMDes Desa Rantau Panjang Periode 2019 - 2025

${ }^{17}$ Data monografi Desa Rantau Panjang Tahun 2020

${ }^{18}$ Hasil Wawancara dengan Kepala Desa Rantau Panjang tanggal 13 Juli 2020

${ }^{19}$ Hasil Wawancara dengan Kepala Desa Rantau Panjang tanggal 13 Juli 2020
} 
c) Administrasi keungan, administrasi sumber-sumber pendapatan dan pengeluaran, dan administasi penghasilan Kepala Desa, Perangkat Desa, BPD dam lembaga pemerintahan lainnya.

d) Menyusun RAB Desa dan penyusunan laporan. ${ }^{20}$

\section{Kepala Seksi ( KASI)}

Kasi Pemerintah Desa Rantau Panjang dijabat oleh bertugas membantu Kepala Desa dalam bidang Operasional yang terdiri atas 2 Orang yaitu:

a) Kasi Pemerintahan dijabat oleh Ayulastri, bertugas Menyusun rancangan regulasi desa, tata praja pemerintahan, pembinaan masalah pertanahan, pembinaan ketentraman dan ketertiban, pelaksanaan upaya perlindungan masyarakat, Kependudukan, penataan dan pengeloaan wilayah, serta pendataan dan pengelolaan profil desa.

b) b.Kasi Kesejahteraan dan Pelayanan dijabat oleh Hamdani, yang bertugas melaksanakan pembangunan sarana prasarana perdesaan, pembangunan bidang pendidikan, kesehatan, dan tugas sosialisasi serta motivasi masyarakat di bidang budaya, ekonomi, politik, lingkungan hidup, pemberdayaan keluarga, pemuda, olahraga, dan karang taruna, melaksanakan penyuluhan dan motivasi terhadap pelaksanaan hak dan kewajiban masyarakat, meningkatkan upaya partisipasi masyarakat, pelestarian nilai sosial budaya masyarakat, keagamaan, dan ketenagakerjaan. ${ }^{21}$

\section{Kepala Urusan (KAUR)}

Kaur Pemerintah Desa Rantau Panjang terdiri dari 2 Orang, masing-masing membidangi yaitu:

a) Kaur Keuangan dijabat oleh Weni Windiyani bertugas membantu Sekretaris Desa Menyusun Rencana Anggaran Kas Desa (RAK Desa) dan Melakukan penatausahaan yang meliputi menerima ,menyimpan, menyetorkan, membayar, menatausahakan dan mempertanggungjawabkan penerimaan pendapatan Desa dan pengeluaran dalam rangka pelaksanaan APBDes.

b) Kaur Tata Usaha dan Umum dijabat oleh Eva Novitasari, bertugas membantu Sekretaris Desa Melasanakan urusan ketatausahan, pengarsipan, administrasi surat menyurat, penataan administrasi Perangkat Desa dan Kantor, penyiapan rapat, pengatministrasian asset, inventarisasi, perjalana dinas, dan pelayanan umum. ${ }^{22}$

\section{Staf Bidang}

Staf Pemerintah Desa Rantau Panjang terdiri dari 3 Orang yaitu

a) Staf Kasi Pemerintahan dijabat oleh Mardani, bertugas membatu kasi bagian umum dalam menyiapkan segala pelaksanaan operasional pemerintahan

b) Staf Kasi Kesejahteraan dan Pelayanan dijabat oleh Arif Noviandi, bertugas membantu kasi kesejahteraan dan pelayanan umum dalam pelaksanaan operasional kesejahtetaan dan umum. ${ }^{23}$

\section{Kepala Dusun}

Kepala Dusun atau kelapa kewilayaan terdiri dari 2 Orang yaitu Kepala Dusun Rantau Timur dijabat oleh Sehandi dan Kepala Dusun Rantau Barat dijabat oleh A. Hamid. AB, tugas dari Kepal Dusun atau Kepala Kewilayahan adalah membantu Kepala Desa dalam pelakasaan kewilayahan. ${ }^{24}$

Berdasarkan hasil wawancara peneliti kepada Kepala Desa, Sekretaris Desa, maka untuk lebih maksimal pelayanan di Desa Rantau rencana kedepan Perangkat Desa akan ditambah menjadi:

1. Semula 2 orang Kasi yaitu 1 orang Kasi Pemerintahan, 1 orang Kasi Pelayanan dan Kesejahtraan akan tambah menjadi 1 orang Kasi Pemerintahan, 1 Orang Kasi Kesejahteraan dan 1 orang Kasi Pelayanan.

2. Semula 2 orang Kaur yaitu 1 orang Kaur Keuangan, 1 orang Kaur Tata Usaha dan umum akan ditambah menjadi 1 orang Kaur Keuangan, 1 Orang Kaur Tata Usaha dan 1 orang Kaur Umum

Hal ini dilakukan agar tidak adanya tumpang tindih tugas dan kewenangan serta untuk melengkapi syarat maksimal desa menjadi desa maju. Tujuan kedepan kepala desa rantau panjang akan mempercepat secara maksimal terkait penertiban administrasi kependudukan karena masih ada masyarakat di desa yang belum mempuyai Kartu Kependudukan (KK) dan Kartu Tanda Penduduk (KTP) agar apabila ada bantuan yang bersifat sosial desa lebih mudah untuk menyalurkan juga tepat sasaran dan memaksimalkan pengesahan kepada organisasi-organisasi masyarakat yang belum mempunyai surat keputusasan (SK) Kepala Desa.

Bentuk pelayanan di desa memang belum maksimal khususnya adaminisrasi kependudukan dikarenakan masih ada penduduk yang tidak mempunyai Kartu Penduduk dan pembenahan kantor desa karena dikantor desa masih belum ada loket pelayanan sehingga apabila masyarakat ingin meminta perlayanan dalam jumlah 1 atau 3 orang terasa sempit. Namun untuk saat ini masih

\footnotetext{
${ }^{20}$ Hasil Wawancara dengan Sekretaris Desa Rantau Panjang tanggal 14 Juli 2020

${ }^{21}$ Hasil Wawancara dengan Kasi Pemerintah Desa Rantau Panjang tanggal 14 Juli 2020

${ }^{22}$ Hasil Wawancara dengan Kaur Tata Usaha Desa Rantau Panjang tanggal 14 Juli 2020

${ }^{23}$ Hasil Wawancara dengan Staf Desa Rantau Panjang tanggal 14 Juli 2020

${ }^{24}$ Hasil Wawancara dengan Kepala Dusun di Desa Rantau Panjang tanggal 15 Juli 2020
} 
belum bisa terlaksanan dikarenakan lokasi ruangan kantor desa yang kecil. Hal serupa disampaikan oleh masyarakat yang meminta pelayanan di Kantor Desa ia mengatakan sebaiknya di Kantor Desa harus ada dipersiapkan loket khusus tempat kita untuk melakukan pelayanan tamu yang datang ke Kantor Desa agar lebih efektif.

Petugas dan yang berwenang dalam menerima pelayanan selain Kepala Desa untuk menjalankan roda Pemerintahan Desa Rantau Panjang Kepala Desa dibantu oleh perangakat desa khususnya adalah Kepala Urusan umum dan staf di Kantor Desa. Segala bentuk dalm bidang adminstrasi pelayanan yang dilakukukan dikantor desa besifat gratis atau tidak dipungut biaya sedikit pun karena segala biaya tersebut sudah ditanggung melalui Anggaran Dana Desa (ADD).

Berdasarkan hasil wawancara kepada Kepala Desa dan Perangkat Desa, yang kemudian disimpulkan bahwa tantangan terbesar Pemerintah Desa Rantau Panjang dalam melakukan pelayanan di masyarakat yaitu:

1. Pada saat masyarakat mengajukan administrasi kependudukan misal pembuatan KK atau KTP persyaratan kelengkapan Dokumentasi yang akan diajukan tidak lengkap sehingga mempersulit dalam penebitan pengajuan tersebut; dan

2. Permasalahan pengajuan pembuatan KTP atau KK yang diberikan kepada Pemerintah Desa Pengurusannya lambat disebabkan antrian di Kabupaten sehingga masyarakat mengeluh mengenai hal tersebut.

\section{Pelayanan Pemerintah Desa Rantau Panjang Menurut Peraturan Menteri Nomor 2 Tahun 2017 Tentang Standar Pelayanan Minimal Desa}

Mempercepat peningkatan kualitas pelayanan kepada masyrakat Desa guna perwujudan kesejahteraan umum sesuai denga kewenangan Desa, perlu menetapkan Standar Pelayanan Minimal Desa (SPM Desa). ${ }^{25}$ Standar Pelayanan Minimal Desa adalah ketentuan jenis dan mutu pelayanan yang merupakan urusan Desa yang berhak diperoleh setiap masyarakat desa secara minimal. Standar pelayanan minimal Desa berdasarkan ketentuan yang dipakai sebagai tatanan penyelenggaraan urusan desa dari Norma, Standar, Prosedur, dan Kriteria (NSPK). ${ }^{26}$

Standar Pelayanan Minimal Desa (SPM Desa) dimaksudkan untuk mendekatkan pelayanan kepada masyarakat, mempermudah pelayanan kepada masyarakat, keterbukaan kepada masyarakat, dan keefektifan pelayanan kepada masyarakat. ${ }^{27}$ Pemerintah Desa Rantau Panjang telah berupaya menjalankan pelayanan semaksimal mungkin sebagaimana yang sudah di jelaskan dalam pembahasan sebelumnya mengenai tugas dan wewenang Pemerintah Desa Rantau Panjang. Selain itu, Pemerintah Desa Rantau Panjang telah melaksanakan pelayanan dengan cara menggratiskan setiap pelayanan pembuatan surat menyurat dengan maksud untuk mendekatkan pelayanan kepada masyarakat. ${ }^{28}$ Serta Kefektifan pelayanan yang telah dilakukan pemerintah Desa Rantau Panjang dalam melakukan pelayanan kepada masyarakat sudah cukup efektif dengan membuat jadwal piket masuk kerja. ${ }^{29}$ Namanya yang masuk dalam jadwal piket sesuai dengan hari yang ditentukan maka ia diharuskan datang lebih awal dari jam masuk kerja. Namun, masih terdapat kekurangan-kekurangan terutama dalam pengurusan administarsi kependudukan yang belum maksimal karena masih ada penduduk yang tidak memiliki Kartu Keluarga (KK) dan Kartu Tanda Penduduk (KTP) serta masih adanya rangap jabatan di bagian Kepala Seksi (Kasi) Pelayanan dan Kesejahteraan serta Kepala Urusan (Kaur) Tatausaha dan Umum. ${ }^{30}$

Surat Keputusan tentang Standar pelayanan Minimal Desa tidak ditetapkan oleh Kepala Desa karena mengenai standar pelayanan minimal pelayanan Desa akan berubah-ubah sesuai situasi jadi untuk dibuat surat keputusan Kepala Desa sulit untuk di tetapkan. Sedangkan, menurut Peraturan Menteri dalam Negeri No. 2 tahun 2017 pasal 2 ayat (1) Kepala Desa Menetapkan SPM Desa; ayat (2) SPM Desa sebagimana dimaksud pada ayat (1) ditetapkan dengan Keputusan Kepala Desa. ${ }^{31}$

Berdasarkan Peraturan Menteri Dalam Negeri Nomor 2 Tahun 2017 Tentang Standar Pelayanan Minimal Desa pasal (5) poin (a) SPM Desa antara lain meliputi penyedian dan penyebaran informasi. ${ }^{32}$ Mekanisme yang dilakukan Pemerintah Desa Rantau Panjang dalam penyedian dan penyampaian informasi melalui Pemasangan baleho; Penempelan surat pengumuman di warung-warung atau tempat-tempat orang berkumpul; Penempelan surat pengumuman di warung-warung atau tempat-tempat orang berkumpul; Penempelan informasi di warung-warung atau tempat-tempat orang berkumpul; dan Desa memerintahkan kepada ketua RT masing-masing untuk menyebarkan informasi dari desa.

Sarana dan prasarana pendukung dalam pelayanan kepada masyarakat di Kantor Desa Rantau Panjang sudah cukup memadai seperti adanya komputer dan ruang tunggu hanya untuk loket pelayanan yang tidak ada. Sedangkan, menurut Peraturan dalam negeri nomor 2 tahun 2017 pasal 11 ayat (4) sarana dan prasarana sebagaimana dimaksud pada ayat (3) huruf (c) antara lain (a) tempat/lokasi pendaftran; (b) tempat pemasukan berkas dokumen; (c) tempat penyerahan dokumen; (d) tempat pelayanan pengaduan; dan (e) perangkat pendukung lainnya. ${ }^{33}$

\footnotetext{
${ }^{25}$ Konsederan salinan Peraturan Menteri Dalam Negeri Nomor 2 Tahun 2017 tentang Standar Pelayanan Minimal Desa

${ }^{26}$ Pasal 1 ayat (9) Peraturan Menteri Dalam Negeri Nomor 2 Tahun 2017 tentang Standar Pelayanan Minimal Desa

${ }^{27}$ Pasal 2 Peraturan Menteri Dalam Negeri Nomor 2 Tahun 2017 tentang Standar Pelayanan Minimal Desa

${ }^{28}$ Hasil Wawancara dengan Kepada Kepala Desa Rantau Panjang tanggal 13 Juli 2020

${ }^{29}$ Hasil Wawancara dengan Sekretaris Desa Rantau Panjang tanggal 14 Juli 2020

${ }^{30}$ Hasil Wawancara dengan Kepala Desa Rantau Panjang tanggal 13 Juli 2020.

${ }^{31}$ Peraturan Menteri Dalam Negeri Nomor 2 Tahun 2017 tenang Standar Minimal Pelayanan Desa pasal (1) dan Pasal (2).

${ }^{32}$ Peraturan Menteri Dalam Negeri Nomor 2 Tahun 2017 tenang Standar Minimal Pelayanan Desa pasal 5 huruf (a).

${ }^{33}$ Peraturan Menteri Dalam Negeri Nomor 2 Tahun 2017 tenang Standar Minimal Pelayanan Desa pasal 11 ayat (4).
} 
Website : http://yustisia.unmermadiun.ac.id/index.php/yustisia

Pelayanan yang dilakukan pemerintah desa saat masyarakat meminta pelayanan mengenai surat-menyurat di Kantor Desa lama proses pembuatan tidak lebih dari 1 (satu) hari kerja. Sesuai dengan Peraturan Menteri No 2 Tahun 2017 Tentang SPM Desa pasal 13 ayat (2) berbunyi dalam hal fasilitasi dan mengoordinasi pengaduan sebagaimana dimaksud ayat (1) paling lama 3 (tiga) hari kerja. ${ }^{34}$

\section{IV.KESIMPULAN}

Pelaksanaan Tugas dan Wewenang Pemerintah Desa Rantau Panjang dalam melayani masyarakat dimana kepala desa selaku pimpinan didesa menjalankan roda Pemerintahan Desa Rantau Panjang sudah berupaya semaksimal mungkin dengan memfungsikan Kasi, Kaur, dan Perangkat Desa lainya. Namun, masih terdapat kekurangan-kekuranan atau yang tidak sesuai dengan Peraturan Menteri Dalam Negeri Nomor 2 tahun 2017 tentang Standar Pelayanan Minimal Desa yaitu Belum efektifnya Administarasi kependudukan karena masih adanya masyarakat yang belum mempunyai data kependudukan seperti KTP dan KK, adanya rangkap jabatan di bagian Kasi dan Kaur, masih belum terlaksana mengenai penetapan Desa Tentang standar pelayanan minimal pelayanan Desa karena tata kelola prosedur pelayanan didesa berubah-ubah sesuai situasi jadi untuk dibuat surat keputusan Kepala Desa sulit untuk ditetapkan dan belum adanya loket loket pelayanan dan kurangnya respon mengenai pengaduan dari masyarakat.

\section{DAFTAR PUSTAKA}

Ellya Rosana, "Dinamisasi Kebudayaan Dalam Realitas Sosial,” Jurnal Al-Adyan, Vol. 12, No. 1 Tahun 2017.

Wahjudi Sumpeno, Perencanaan Desa Terpadu Edisi Kedua, Read. Reinforcament Action and Development, 2011

Soerjono Soekanto \& Sri Mamudji, Penelitian Hukum Normatif (Suatu Tinjauan Singkat), Rajawali Pers, Jakarta, 2001.

Sifuddin Azwar, Metodologi Penelitian, Yogyakarta Pustaka Pelajar, 1998.

Sutrisno Hadi, Metedologi Research, Yogyakarta: Adi Offsed, 1993.

Undang-Undang Nomor 6 tahun 2014 Tentang Desa

Undang-Undang Nomor 25 Tahun 2009 Tentang Pelayanan Publik

Peraturan Menteri Dalam Negeri Nomor 2 Tahun 2017 tentang Standar Minimal Pelayanan Desa.

RPJMDes Desa Rantau Panjang Periode 2019 - 2025

Data monografi Desa Rantau Panjang Tahun 2020

Hasil Wawancara dengan Kepala Desa Rantau Panjang tanggal 13 Juli 2020

Hasil Wawancara dengan Sekretaris Desa Rantau Panjang tanggal 14 Juli 2020

Hasil Wawancara dengan Kasi Pemerintah Desa Rantau Panjang tanggal 14 Juli 2020

Hasil Wawancara dengan Kaur Tata Usaha Desa Rantau Panjang tanggal 14 Juli 2020

Hasil Wawancara dengan Staf Desa Rantau Panjang tanggal 14 Juli 2020

Hasil Wawancara dengan Kepala Dusun di Desa Rantau Panjang tanggal 15 Juli 2020

Khalil Muslim, Pelaksanaan Tugas Dan Fungsi Pemerintah Kecamtan Di Kota Makasar Dalam Pemberian Pelayanan Kepada Masyarakat, Skripsi, 2013.

Jamin Potabuga, "Peranan Kepala Desa Dalam Pelayanan Publik," dalam e-journal “Acta Diurna” Volume IV. No.2. Tahun 2015.

Ricca Fauzia, Peranan Pemerintah Desa untuk mendorong Partisipasi Masyarakat dalam Pembangunan Desa di Desa Ngimbangan Kecamatan Mojosari Kabupaten Mojokerto. Skripsi: 2017.

\footnotetext{
${ }^{34}$ Peraturan Menteri Dalam Negeri Nomor 2 Tahun 2017 tenang Standar Minimal Pelayanan Desa pasal 13 ayat (2).
} 